of older people in the total productive and community effort and that educators hold the key to success in doing this. Educators know, too, that one of the aims of the democratic nations that must not be lost sight of during this critical period is to enable all their citizens to lead the fullest possible lives.

\section{Clark Tibbitts}

Chairman, Committee on Education for an Aging Population, DepartMENT OF Adult Education, NEA

\title{
Preparation for Living in the Later Years
}

\section{Wilma Donahue}

Director, Institute for Human Adjustment, University of Michigan

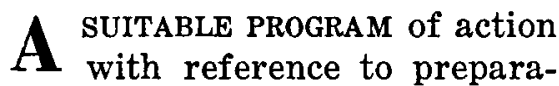
tion for living in the later years is difficult to propose. Such a task is rendered complex because there are a large number of unknown and unstable factors involved. In the first place, old age is not a separate, static period of life. The years of later maturity extend over several decades, during which the individual undergoes continuous changes which may be as profound as those occurring during the first forty years of life.

Secondly, there is no reason to believe that the old person of tomorrow will be exactly like the old person of today. Medical science assures us that it already has the knowledge and skill necessary to retard physiological aging and to insure prolonged vigor. Moreover, old people, like any other age group, are in large part the product of their life experiences. Since these are not the same for any two generations, and since the pace of contemporary life is so greatly accelerated, the differences between generations of old people may be greatly exaggerated in the future.

Thirdly, the situation with reference to old people is an evolving one. If present interest and effort are maintained, the old person of tomorrow will enjoy opportunities for a life of continued usefulness and will possess a role in society as well defined as that of any other major age group. The accumulation of these factors leads to the obvious conclusion that, at the present time, we do not know the pattern of tomorrow's older person.

Education then has two problems with which it must cope in 
planning for the preparation of people for living in the later years. It must provide guidance to the old and the near-old of today, and, in addition, it must develop a dynamic concept of education for an aging population which will allow for the evolution of a new type of old person functioning in a new social milieu.

\section{Education and the Old Person of Today}

With reference to the old and the near-old-the more than $\mathbf{1 1}$ million people who have without expectation or preparation achieved the age of 65 and beyond-education must take immediate steps. Programs must be introduced at once which will help this group of men and women find the solution to the problem which baffles them so much-how to live a productive, healthy, happy life in a society which resents old age and rejects those who are old.

Educators must lead the way, putting aside prejudices and preconceived notions about old age, and taking the facts into account. The facts are that certain physiological changes do take place which are, as far as is known today, the results of the aging process and not of disease. The aging individual undergoes certain changes in the pigmentation of cells, in the elasticity of body tissue, in the rate of recovery after illness, in the ease with which food is converted into energy, in the sensitivity of the sense cells, and in the speed with which sensorymotor reactions occur. Other changes about which old people complain are not so clearly the result of the aging process but may, on the other hand, reflect our failure to provide the mature adult with stimulation and opportunity for the continuous development of personal resources through life-long learning. We refer to the difficulty which old people report with reference to learning and the recall of specific information upon command, and the apparent loss of ability to deal with quantitative subjects such as mathematics. Some experimental evidence seems to indicate that these losses may be, at least in part, the result of lack of practice rather than loss of ability. Even more questionable as the inevitable outcomes of the aging process are the negative concepts of personality disintegration in the aged and decline in intellectual ability. Not until society discontinues its rejection of the old and provides opportunity for them to fulfill their needs for a secure, productive old age will it be possible to measure how much of the change in personality is the 
actual result of aging and how much is due to the individual's attempt to adjust to hostile circumstances. Also of significance to the educator is the fact that the range of individual differences in efficiency of performance at any age level is much greater than the year-to-year changes associated with aging.

Programs to assist those who are already old should be designed to achieve several objectives:

1. To provide information about the aging process and to help in the development of a philosophy with regard to growing old.

2. To furnish information regarding the special problems which arise as a result of aging.

3 . To provide training in techniques for attaining a maximum level of personal adjustment.

4. To provide training and retraining in skills and knowledge which will permit continued employment and creative and socially significant activity.

\section{How can these objectives be achieved?}

Because virtually all old people need the opportunity to participate in educational programs, there can be no single approach and no single responsible agency. The adult educators in industry, in unions, in organized community groups, in churches, in fraternal organizations and clubs have as great a responsibility in preparing people for living in the later years as have those who are working in formal educational institutions.

Fortunately, there are already examples of programs in operation which may serve as points of reference in developing new ones. At the University of Michigan a course now called "Living in the Later Years" has been offered by the Institute for Human Adjustment through the Extension Service for several years. It is designed to attain the first two of the previously enumerated objectives and indirectly to contribute to the third. The content of the course is based upon the expressed needs of older people as determined through personal interviews. 1 The series of twelve noncredit lectures and discussions include the following topics: aging in American life; psychological aspects of growing older ; physical health and care; nutritional needs; maintenance of mental health; family life, living arrangements and housing; financing the later years; employment opportunities; citizenship opportunities and obligations; creative and recreational activities; legal problems; and religious opportunities and satisfactions. The students in the course have ranged from 18 to 90 years of age; the modal age has usu-

${ }^{1 T i b b i t t s, ~ C l a r k . ~ " A g i n g ~ a n d ~ L i v i n g, " ~ A d u l t ~ E d u c a t i o n ~ B u l l e t i n, ~ 13, ~ 1948, ~}$ 204-211. 
ally been in the early sixties. Approximately $25 \%$ of the students have been professional workers who serve or are planning to serve old people. One group of 150 students was asked to report their reasons for electing the course. The replies were analyzed into five categories. Table I indicates the number of replies falling in each category. lar course in one of the metropolitan branch libraries and used other students from the class as lecturers. This program has now spread to other library branches in the city. Other groups of students are at present discussing ways and means to procure more adequate housing for themselves, and still another is exploring the possibilities for establishing a

\begin{tabular}{|l|l|}
\hline \multicolumn{1}{|c|}{ TABLE I } \\
Stated Reasons for Electing a Course on Aging \\
\hline \multicolumn{1}{|c|}{ Reason Categories } & $\begin{array}{c}\text { Number } \\
\text { Giving Reason }\end{array}$ \\
\hline 1. To secure assistance with problems of & 49 \\
2. To combat loneliness and make friends & 29 \\
3. To learn about activities, new interests, & 36 \\
$\begin{array}{l}\text { jobs, and ways to be useful } \\
\text { To gain information about aging (non- } \\
\text { professional) }\end{array}$ & 86 \\
5. To gain information about old people & 53 \\
(professional) & \\
\hline
\end{tabular}

No systematic study or tabulation of the outcomes of the course has been attempted, but some casual information is available. Community clubs for older people started by the students drew the attention of the community to the needs of the older citizen, with the result that recreational facilities and leadership have been provided and opportunities have arisen for the formation of other groups. ${ }^{2}$ One of the students planned a simi- community center including a store for the sale of items produced by themselves and other older people. Individuals have been assisted in achieving a better personal adjustment because they have found a useful outlet for their energies in serving other old people, in participating in research activities under the supervision of the Institute staff, $^{3}$ in the formation of new and enduring friendships, and in the opportunity for discus-

${ }^{2}$ Hunter, W., Tibbitts, C. \& Coons, D. "A Recreational-Educational Experiment," in Planning the Older Years (edited by Wilma Donahue and Clark Tibbitts). Ann Arbor: University of Michigan Press, 1950. 
sion and for satisfying interpersonal relationships with their peers who have similar problems and needs.

Other colleges and universities are now offering similar courses for old people. At least one course has been given which was designed to achieve the third objective-training in techniques for attaining personal adjustment. This course, entitled "Problems of Aging", was offered at Cleveland College. The enrollment was limited to a small number, and through the group process the students were assisted in working out their individual problems.

Educational plans for achieving the various objectives need not be and fortunately are not restricted to formal educational units. Wise educators are going where older people are. As a result, we already have a few pioneering programs which will serve as guides to future planning. Some industrial concerns are attempting to assist their older workers to prepare for retirement. ${ }^{4}$ Unions are becoming more cognizant of the need to examine the meaning of the newly found leisure of their retired members. A few homes for old people have instituted programs which are helping some of their residents to return to an independent life. Communities are organizing lecture series and institutes to discuss some of the more pressing and practical problems of older people. Radio and television programs are presenting older people and their needs in an instructive and interesting way. At least one newspaper (Chicago Daily News) is devoting a daily column to the problems and opportunities of the older person of today.

As yet not much has been accomplished with regard to the fourth objective-the retraining of the aging person for the performance of new skills or the pursuit of new interests. However, the pattern of cooperative training programs which have been established for youth might well be followed in the retraining of old people. An integrated program carried on by industry, the community and the school could assist the older individual to model a new pattern of living in the later years which would result in maximum satisfaction to himself as well as usefulness to an employer and to the community.

Courses, institutes, special

"Donahue, Wilma. "An Experiment in the Restoration and Preservation of Personality in the Aged," in Planning the Older Years.

"Robson, R. B. "Experiment in Education of the Older Worker," Industrial Medicine \& Surgery, 18, 1949, 365-367. 
training sessions and general educational opportunities are the only programs that our educators are offering at present, and these are available on but a limited basis. At least one suggestion has been made that colleges for old people be established as a regular part of the educational system. ${ }^{5}$ Such colleges, it is proposed, should have their own campuses, dormitories, school buildings, recreational grounds, instructional staffs and curricula. The latter should include training in how to live life as an old person. Information regarding the changed physiological needs and functions should be provided; training in proper eating habits and diets should be given; daily schedules of rest and of personal hygiene should be practiced to establish such new habits as are needed; opportunity for gaining new knowledge and for the development of new interests or the pursuit of old ones, along with training in particular skills, should be available. An integral part of the curriculum should center around training for living with others and for establishing and maintaining satisfactory interpersonal relationships. All these activities should be directed toward the ultimate goals of life after "graduation" from this college. A similar educational plan, which could be carried out by the community college or the high school, is suggested for those who would not be eligible for "college".

Provocative as these suggestions are, we cannot wait for their full development before taking steps which may eventually lead to full-scale schools for older people. In almost every community there is a significant number of old people who are today in need of opportunity to prepare, albeit belatedly, for their later years. At the same time, in almost every community, large parts of the school plant close down promptly at five o'clock or earlier. Such facilities as are now in existence could be put to use at the cost of a small additional staff, which frequently would be available among the older people themselves.

One service to be introduced in a full-scale program is that of counseling for older people. ${ }^{6}$ The experience of those educators who already have programs for old people is that the older

${ }^{5}$ Henry S. Curtis in a private communication to the author.

"Donahue, Wilma. "Age with a Future: the Role of Education," in Social Work in the Current Scene (Volume II of Proceedings of the 77th Annual Meeting of the National Conference of Social Work). New York: Columbia University Press (in press). 
individual is just as anxious for guidance in working out his vocational, family and social plans as are younger people. This need can be easily understood when we consider that one of the characteristics of life in the later years is the loss of friends and families. Many older people literally have no one with whom they can review their problems as they attempt to work out solutions. Redirection of effort and activity should be based upon available scientific knowledge with regard to the measurement of aptitudes, occupational demands and placement, and economic trends. The professional counselor should be employed preferably as part of a community team to serve old people or as a part of the regular staff of the adult education school.

\section{Education and the Old Person of Tomorrow}

Continued growth and development resulting in maximum productivity which is in harmony with changing capacities and energies would seem to be a reasonable goal of education for an aging population. In fact, education will play a very significant part in determining what the old person of tomorrow will be. Properly conceived, it will prepare the individual at the appropriate time for each phase of life, will promote his orderly transition from one period of life to another, and will prevent the disruption of the continued growth and use of his personal resources at any age level.

Recognizing that we have no knowledge about the older person of the future other than the limited information we have about the old person of today, there is still much to be done to initiate a dynamic educational program designed to meet the needs of the aging in the changing scene of modern life. Continuous learning throughout life should be the accepted standard of individuals and educators alike. With the assurance from science of prolonged years of vigor and increased longevity, it should become less difficult to convince people of the need to prepare for continued usefulness to society. If this changed attitude is brought about, it should be reflected in demands from the many millions of aging people for increased educational opportunity to ready themselves for their later years. At least by middle age they will be seeking information and training which will increase their opportunities for employment following retirement from regular occupations. They will want knowledge with reference to the maintenance of income and of a reasonable 
standard of living throughout life. They will need information regarding healthful living practices, methods for retarding the aging process, and the control and avoidance of chronic disease. They will require knowledge and counseling in the techniques which in later life will ensure effective family and group membership and maximum personal adjustment. They will apply for training in skills and creative activities which bring the same satisfactions in old age as do similar activities in youth and maturity. Finally, they will want guidance in the evaluation of their own roles as effective citizens on the local, state and national scene.

Further, it is indicated that existing curricula at all school levels should be examined and modified to provide for an interpretation to all ages of the potentialities of older people, their role in society, and the significance and value of aging. The young should know what it will mean to live in a population heavily weighted with older people and how this will be reflected in the various cultural phases of life. They should learn to appreciate the significance of the need to establish a life pattern which will permit many decades of independence and productivity. They should be taught that preparation for suc- cessive phases of life is a continuous process and, accordingly, that they must pursue education throughout life.

Another area needing attention with reference to the old person of tomorrow is the determination of the contributions and responsibilities of the various institutions for preparing people for living in the later years. Perhaps the types of responsibilities which are now accepted will not require substantial modification. However, if the roles of public schools, technical schools and institutes, colleges and universities, libraries, governmental agencies, unions, civic and fraternal groups and the church were better defined, and if integrated programs and common goals were established, the needs of the aging would be served more adequately. For example, it would be of little value for industry to develop a program designed to prepare people for a productive and worthwhile life after retirement if the community had not made the necessary provisions for those so prepared to make use of their knowledge. The same may be said for all other educational agencies.

Education has already recognized the need to extend its concepts of adult education to include the aging population. The appointment of a Committee on 
Education for an Aging Population by the Department of Adult Education is one evidence of this interest; the more recent plan to establish a single adult education organization which will emphasize the needs of the aging is another. But action on the part of educators at the local level is also needed. In the absence of established patterns, experimental programs and modifications of existing programs and courses to include the aging should be initiated, reported, and their outcomes evaluated. Those techniques, methods, materials and concepts which promote the productivity and happiness of aging people should be retained, and new programs based on the conclusions from previous research should be developed.

\section{Community Attitudes and the Older Citizen}

\section{Arthur Carstens}

Assistant Head of Extension Services, Institioie of Industrial Relations, University of California, Los Angeles

THHERE IS A NEED on the part 1 of all community leaders to re-examine their attitudes and practices with respect to older persons. Today one-third of all American voters are over $\mathbf{5 0}$ years old; 25 years hence $40 \%$ will be. Age can become a powerful coalescing force for a political or social block. The aged may, and do in some cases, rank with farm, labor and veteran groups as a powerful influence in our political and social life. It may be too early to suggest a struggle between youth and age, but as older citizens become more numerous, the latent possibilities exist. A struggle cer- tainly will develow if we continue to increase the number of older citizens and continue to lower the age at which they are compelled to retire from useful work.

During the past half century there have been unprecedented changes in the economic status of older workers. In 1890, for example, $70 \%$ of the men 65 years of age and older were in the work force. By 1940, this figure had declined to $42 \%$. The net result of the rise in the number of aged combined with decreasing labor force participation has been a tremendous drive for security. This drive 